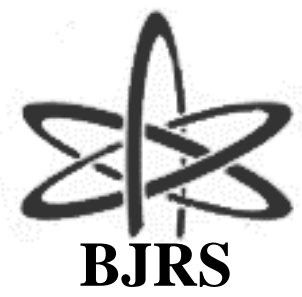
BRAZILIAN JOURNAL
OF
RADIATION SCIENCES
09-01A (2021) 01-14

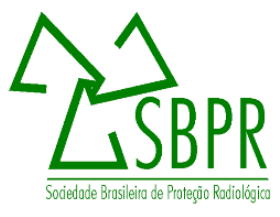

\title{
Estimated Pollutant Load from Nuclear and Energy Research Institute (IPEN/CNEN-SP, BRAZIL)
}

Tatiane Bernardino de Seixas Carvalho da silva, Cintia Carvalho de Oliveira, Joyce

Rodrigues Marques, Mainara Generoso Faustino, Thamiris Brandino Stellato,

Lucilena Rebelo Monteiro, Maria Aparecida Faustino Pires, Marycel Elena Barboza

\section{Cotrim}

${ }^{a}$ Nuclear and Energy Research Institute / Environment and Chemistry Center, 05508-000, São Paulo, São Paulo, Brazil

tatianebscs@live.com; luciremo@uol.com.br

\begin{abstract}
The quantification of the pollutant load received by a water body is one necessary step to keep its original standards, irrespective of the releasing source. Thus, to monitor and control the content of pollutants released in a water body assures the water will remain free from excessive pollution. Also, no harm to human health and the environment will occur. Hence, this paper aims to estimate the pollutant load of sanitary wastewater released by the Nuclear and Energy Research Institute (IPEN / CNEN-SP) in 2015 and 2016. The analysis of $\mathrm{Cd}, \mathrm{Pb}, \mathrm{Cu}, \mathrm{Cr}$, Zn, Ba, Ni, Mn, Fe, B, and Sn was performed by Inductively Coupled Plasma Optical Emission Spectrometry (ICP-OES). These metals and the total fixed solids were used to estimate the pollutant load. Wastewater flow measurement was carried out using bromide $\left(\mathrm{Br}^{-}\right)$as a tracer and with the values from IPEN's annual water consumption. Since 2006, this is performed as part of the Environmental Monitoring Program (PMA-Q), in compliance with the current Brazilian Environmental Legislation and with the Term of Conduct Adjustment requirements, agreed with the Brazilian Institute of Environment and Renewable Natural Resources (IBAMA). Even the pollutants load has increased in 2015 and 2016, the monitoring frequency and water consumption have diminished in the last years. These facts increase the uncertainties in the monitoring and could lead to noncompliances with the monitoring laws.
\end{abstract}

Keywords: metals, total fixed solids, bromide tracer. 


\section{INTRODUCTION}

In Brazil wastewater management did not receive the necessary attention until 1960, when the first federal law, dealing with water pollution, was enacted and established a necessity of treatment before wastewater release [1], although the development of environmental legislation has begun before it. Since 1981, the National Environment Council (CONAMA) has been responsible for regulating the industrial release of wastewater, to control and regulate it as much as possible, to keep water bodies quality.

The last CONAMA Resolution regarding wastewater release was Resolution\# 430 published in 2011, that provides guidelines and standards regarding the release of wastewater in water bodies. This resolution states that only previously treated wastewater can be released in water bodies. Minimum requirements and conditions for wastewater releases are established in this Resolution and others in force, as well. Thus, to all potentially affecting substances, maximum allowed values were established for the operation of a receiving water body [2].

A "Polluting Load Declaration" must be presented every year up to March $31^{\text {st }}$, by the responsible for the potential polluting source, referring to the previous year [2]. The environmental agency has to establish the maximum polluting load of the substance release likely to be present or being formed in its productive process [2].

The CONAMA Resolution\# 357/05 defines polluting load as the quantity of a specific polluting released in the receiving water body [3]. The wastewater flow rate (quantitative variable) and the concentrations of the substances in this wastewater (qualitative variable) are required variables because these are conditions changing on time. Then, the total released load is quantified. Any change in the release patterns can be identified (e.g. changes between dry and rainy periods) [3].

Besides, using just concentration values is not possible to provide information, such as the identification of the pollutant source and define strategies for restoring and controlling the content of pollutants [4].

The estimate of the polluting load received in a given water body is the beginning of the monitoring and controlling procedures. Even though the Nuclear and Energy Research Institute (IPEN) was founded in 1956, the estimation of total solids and metals its releases have been 
evaluated just since 2013 [2,5]. Once the institute was settled before the instauration of the Brazilian Environmental Regulations, this venture was not prepared to meet the current requirements, so was signed the Term of Conduct Adjustment (TAC), agreed with the Brazilian Institute of Environment and Renewable Natural Resources (IBAMA). To define the institute's obligations to adequate its activities and ensure it is not affecting the environment and its surroundings.

Since then, the Environmental Monitoring Program for Chemical Compounds (PMA-Q) was instituted at IPEN and each time new actions have been taken to meet TAC requirements, as the estimation of pollutant load since 2013.

As a continuous and yearly process, this paper discusses the 2015 and 2016 estimates of metals polluting load ( $\mathrm{Ba}, \mathrm{Sn}, \mathrm{Cd}, \mathrm{B}, \mathrm{Cr}, \mathrm{Cu}, \mathrm{Fe}, \mathrm{Mn}, \mathrm{Pb}, \mathrm{Ni}$ and, $\mathrm{Zn}$ ) and fixed total solids released. The wastewater flow rate measured by Silva et al. [6] and the polluting load estimates from Marques et al. in 2013 and 2014 [7] are compared with the more recent values measured in the present work. The IPEN water consumption between 2012 and 2016 [8] was used to correct the estimated quantities.

\section{MATERIALS AND METHODS}

\subsection{Wastewater colletion}

Samples were collected at the Wastewater Monitoring Station (EME), located near the north entrance of IPEN (geographical coordinates $23^{\circ} 33^{\prime} 43.48^{\prime \prime S} 46^{\circ} 44^{\prime} 11.71 " \mathrm{~W}$ ). The collection is performed automatically by using a peristaltic pump, with a $1.0 \mathrm{~L} \mathrm{~min}^{-1}$ flow rate, working nine times per day, every hour. In 2015, the sampling was regularly carried out in March, April, and May, and in 2016 in June, July, September, and November. Collections were not carried out every month due to failures in the collection system. An aliquot of $50 \mathrm{~mL}$ of each daily sample was used to compound a weekly sample, acidified with nitric acid to analytes solubility preservation. In 2015, 11 weekly samples were analyzed from March, April, and May. In 2016, weekly from June, July, September, and November were processed.

The collection process met São Paulo`s Environmental Company - CETESB guidelines to environmental sample collection and preservation [9] and the Standard Methods for the Examination of 
Water and Wastewater [10]. Samples were filtered and digested accordingly to EPA 3015 [11], at Environment and Chemistry Center (CEQMA) at IPEN.

\subsection{Chemical analysis}

To analyze the metals and semimetals ( $\mathrm{Cd}, \mathrm{Pb}, \mathrm{Cu}, \mathrm{Cr}, \mathrm{Zn}, \mathrm{Ba}, \mathrm{Ni}, \mathrm{Mn}, \mathrm{Fe}, \mathrm{B}$, and $\mathrm{Sn}$ ), the Inductively coupled Plasma Optical Emission Spectrometry (ICP-OES) was used. The analysis conditions are presented in Table 1. The quantification limits (LOQ) for the method are shown in Table 2. The usual relative standard deviation associated with the measurement of standards and reference material below $16 \%$, all the information about this method validation was published by Marques [1].

Table 1: ICP-OES method conditions

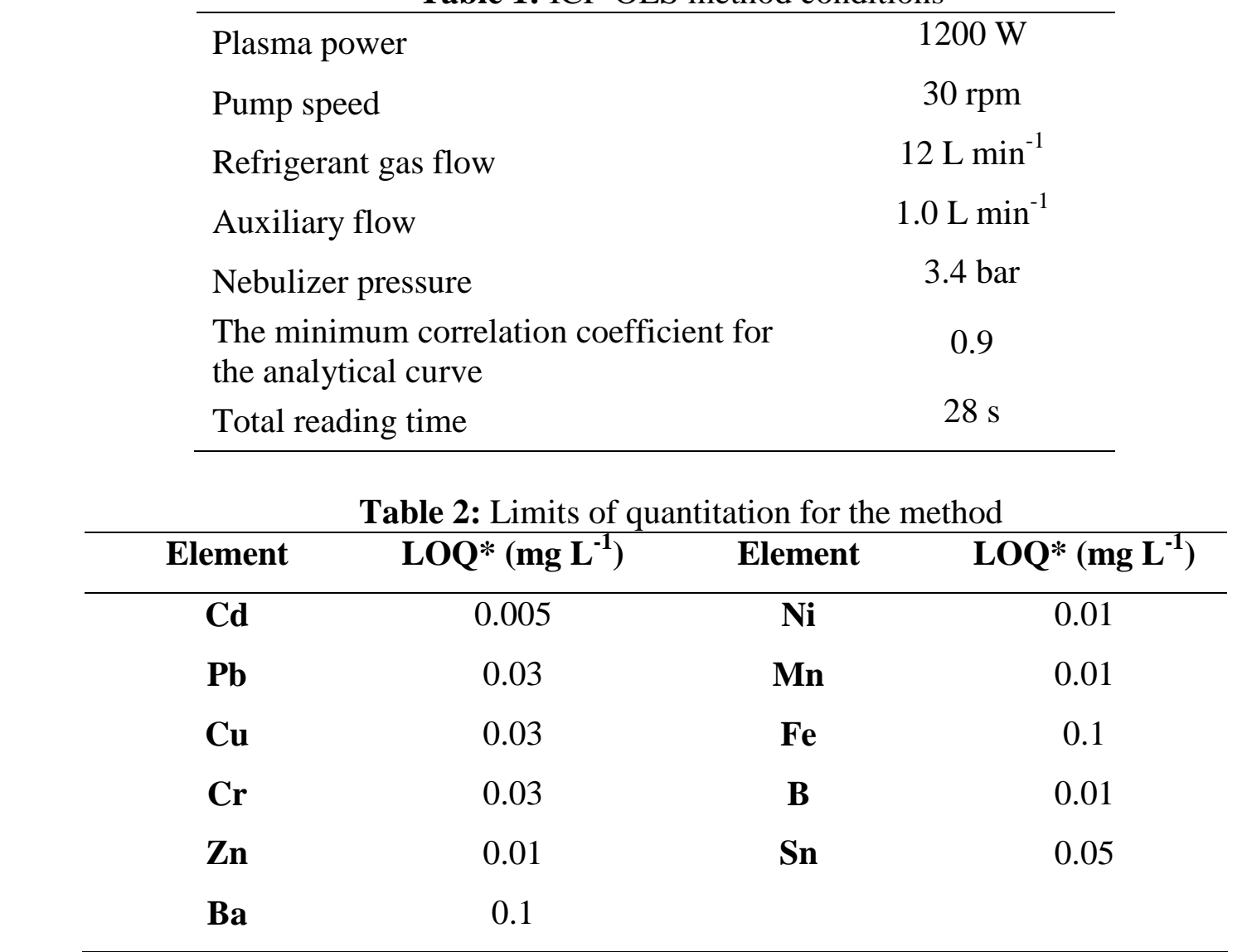

*LOQ $=$ Limit of Quantitation 


\subsection{Solids Determination}

According to the report published by CETESB in 2009, solids are all the physical material that remains as residue, even after evaporation, drying, or calcination of samples [12]. The estimation of fixed total solids (FTS) allows comparing the results with the metals polluting load, since the FTS, in general, are composed of metal oxides, among other residues. So, the sum of the oxides cannot be higher than the FTS polluting loads, being used as an index of evaluation of metals polluting load.

The gravimetric method was used for solid series determination [13]. The determination of FTS and Volatile Total Solids (VTS) was used to calculate Total Solids (TS), according to Equation 1.

$$
T S=F T S+V T S
$$

The FTS are the stable inorganic salts and the VTS instable inorganic salts, as ammonium salts, magnesium carbonate plus organic matter [13].

\subsection{Polluting Load}

To calculate the polluting load of a specified element is important to consider some information, as the amount of the element and wastewater flow rate, according to Equation 2. IPEN`s wastewater flow rate was determined by Silva et al., using bromide as a tracer, the result obtained was $10.5 \pm$ $3.1 \mathrm{~m}^{3} \mathrm{~h}^{-1}$ [6]. In this model IPEN annual water consumption was also considered to evaluate metal and TS polluting load estimated [8].

$$
m(x)=C(x) * Q_{\text {wastewater }}
$$

$m(x)=$ Pollutant Load of a Specific Element $\left[\mathrm{g} \mathrm{week}^{-1}\right]$;

$C(x)=$ Amount of the element $\left[\mathrm{mg} \mathrm{L}^{-1}\right]$;

$Q_{\text {wastewater }}=$ Wastewater Flow Rate $\left[\mathrm{m}^{3} \mathrm{~h}^{-1}\right]$.

\section{RESULTS AND DISCUSSION}




\subsection{Flow Rate and Water Consumption}

The first estimation of IPEN`s polluting load was carried out by Marques et al, where was determined that IPEN released about 1,064 $\mathrm{kg} \mathrm{month}^{-1}$ of pollutant load in 2013 and 2014. However, this result considered IPEN`s wastewater flow rate determined by Silva et al. and an operating regime of $24 \mathrm{~h}$ a day and 7 days a week. In 2015, IPEN`s water consumption was disclosed and knowing that the water consumption in 2013 and 2014 was about 285 and $294 \mathrm{~m}^{3}$ week $^{-1}$, respectively. With that information, it was possible to suggest that the pollutant load was super estimated.

In this paper, the operation regime was considered to be $8 \mathrm{~h}_{\text {day }}{ }^{-1}, 5$ days a week, as presented in Table 3, therefore, a weekly flow rate has more accurate values.

Even considering, the above-mentioned operating regime, the flow rate of $420 \mathrm{~m}^{3} \mathrm{week}^{-1} \mathrm{ex}^{-}$ ceeded the institute water consumption of about $290 \mathrm{~m}^{3}$ week $^{-1}$ but was considered close enough to it. So, this operating regime was more adequate to the estimations being carried out and a significant change is observed in the polluting load results [7]. When compared to the estimated flow rate declared by Marques et al., a significant change is observed in the polluting load results [7].

Table 3: Water consumption and flow rate estimations in IPEN, considering different operating

\begin{tabular}{|c|c|c|c|c|c|c|c|}
\hline \multirow[b]{2}{*}{2012} & \multicolumn{4}{|c|}{ Water Consumption [8] } & \multicolumn{2}{|c|}{ Flow Rate Estimation [6] } & \multirow[b]{2}{*}{ unity } \\
\hline & 2013 & 2014 & 2015 & 2016 & $\begin{array}{c}\text { Operating } \\
\text { regime } \\
\text { 24h/7days [4] }\end{array}$ & $\begin{array}{l}\text { Operating } \\
\text { regime } \\
\text { 8h/5days }\end{array}$ & \\
\hline 15,56 & 13,70 & 14,10 & 10,96 & 7,62 & 84,672 & 20,160 & $\mathrm{~m}^{3}$ year $^{-1}$ \\
\hline 1,30 & 1,14 & 1,18 & 914 & 635 & 7,056 & 1,680 & $\mathrm{~m}^{3}$ month $^{-1}$ \\
\hline 324 & 285 & 294 & 228 & 159 & 1764 & 420 & $\mathrm{~m}^{3}$ week $^{-1}$ \\
\hline
\end{tabular}

\subsection{Polluting Load of Metals and Semimetals}

In 2015 and 2016, the IPEN`s estimated polluting load considered changes in the flow rate, according to the operating regime. The values in 2013 and 2014 were comparable considering the 
same operating regime ( $8 \mathrm{~h}$ a day e 5 days a week). Table 4 shows the concentration values obtained with each element in the periods.

Between 2015 and 2016, Fe presented results between 2.0 and $8.0 \mathrm{~kg} \mathrm{month}^{-1}$ (Figure 1). As Marques et al. [7] pointed out, the Fe monthly polluting load varied between 6.0 and $16 \mathrm{~kg} \mathrm{month}^{-1}$ in 2014 and 4.0 e $9.0 \mathrm{~kg} \mathrm{month}^{-1}$ in 2013, considering a superior operating regime (24h a day, 7 days a week). This variation cannot be explained by the difference in flow rate estimation. Considering the proper correction to the operating regime, these values would correspond to 1.4 and $3.8 \mathrm{~kg} \mathrm{month}^{-1}$ in 2013 and 2014. So, in 2015 and 2016, an increase in Fe polluting load was observed. The presence of Fe in the effluent could be originated from soil leaks entering the wastewater pipes. Once in contact with organic matter and oxygen depleted waters, insoluble $\mathrm{Fe}$ oxides are converted to dissolved $\mathrm{Fe}^{+2}$ and $\mathrm{Fe}^{+3}$ soluble species. Iron is also one element frequently present and easily removed with the usual wastewater treatment processes offering no harm to the general population.

Table 4: Range of concentration values for each element

\begin{tabular}{c|cc}
\hline $\begin{array}{c}\text { Metals and Semi-metals } \\
{\left[\mathbf{m g ~ L}^{-\mathbf{1}}\right]}\end{array}$ & $\mathbf{2 0 1 5}$ & $\mathbf{2 0 1 6}$ \\
$\mathrm{Cd}$ & $0.02-0.03$ & $0.02-0.02$ \\
$\mathrm{~Pb}$ & $0.02-0.06$ & $0.02-0.04$ \\
$\mathrm{Cu}$ & $0.02-0.05$ & $0.02-0.41$ \\
$\mathrm{Cr}$ & $0.04-0.04$ & $0.04-0.04$ \\
$\mathrm{Zn}$ & $0.04-0.10$ & $0.02-0.71$ \\
$\mathrm{Sn}$ & $0.10-1.79$ & $0.10-0.10$ \\
$\mathrm{Ni}$ & $0.01-0.30$ & $0.01-0.03$ \\
$\mathrm{Fe}$ & $0.94-4.19$ & $1.11-8.22$ \\
$\mathrm{Ba}$ & $0.02-2.13$ & $0.01-0.11$ \\
$\mathrm{Mn}$ & $0.03-0.39$ & $0.03-0.16$ \\
$\mathrm{~B}$ & $0.02-0.35$ & $0.02-0.03$ \\
\hline
\end{tabular}


Figure 2 presents the monthly average of Fe polluting load, which corresponds to $2.6 \mathrm{~kg} \mathrm{month}^{-1}$ and $4.5 \mathrm{~kg} \mathrm{month}^{-1}$ in 2015 and 2016, respectively. While in 2013 and 2014 the monthly average was $2.6 \mathrm{~kg} \mathrm{month}^{-1}$ and $2.3 \mathrm{~kg} \mathrm{month}^{-1}$, respectively.

The monthly polluting load of $\mathrm{Cd}, \mathrm{Pb}, \mathrm{Cu}, \mathrm{Cr}, \mathrm{Zn}, \mathrm{Sn}, \mathrm{Ni}, \mathrm{Ba}, \mathrm{Mn}$, and $\mathrm{B}$ (Figure 3), in its majority, was inferior to $1.0 \mathrm{~kg} \mathrm{month}^{-1}$ in 2015 . The single exception was observed in July 2016 , when $\mathrm{Sn}$ was $1.2 \mathrm{~kg} \mathrm{month}^{-1}$ and $\mathrm{Ba}$ was $1.0 \mathrm{~kg} \mathrm{month}^{-1}$. Both $\mathrm{Sn}$ and Ba used in PVC stabilizers can be mobilized by higher concentrations of dissolved salts in wastewaters. Barium is commonly used in households and industrial facilities as a rodenticide [14]. However, $\mathrm{BaCO}_{3}$ is highly poisonous and presents complex toxicology, in wastewaters with the presence of sulfates, $\mathrm{Ba}$ becomes insoluble, as $\mathrm{BaSO}_{4}$ that offers no harm to the general population.

In 2016, after Fe, the element that presented the monthly average the higher was Zn (Figure 4) with $0.3 \mathrm{~kg} \mathrm{month}^{-1}$, followed by $\mathrm{Sn}\left(0.16 \mathrm{~kg} \mathrm{month}^{-1}\right), \mathrm{Mn}, \mathrm{Cu}, \mathrm{Ba}, \mathrm{Cr}, \mathrm{Cd}, \mathrm{Pb}$, and $\mathrm{B}$. During all the assessed period, elements polluting load was inferior to $0.4 \mathrm{~kg}$ month $^{-1}$. While in 2013 and 2014 results were inferior to $0.7 \mathrm{~kg} \mathrm{month}^{-1}$.

In 2015, to other metals, the average monthly polluting load, showed in Figure 4, decrease in the order $\mathrm{Sn}, \mathrm{Ba}, \mathrm{Mn}, \mathrm{Zn}, \mathrm{B}$, and $\mathrm{Ni}$ followed by $\mathrm{Cd}, \mathrm{Pb}$, and $\mathrm{Cu}$. With a maximum of $0.39 \mathrm{~kg} \mathrm{month}^{-1}$ and a minimum of $0.03 \mathrm{~kg} \mathrm{month}^{-1}$.

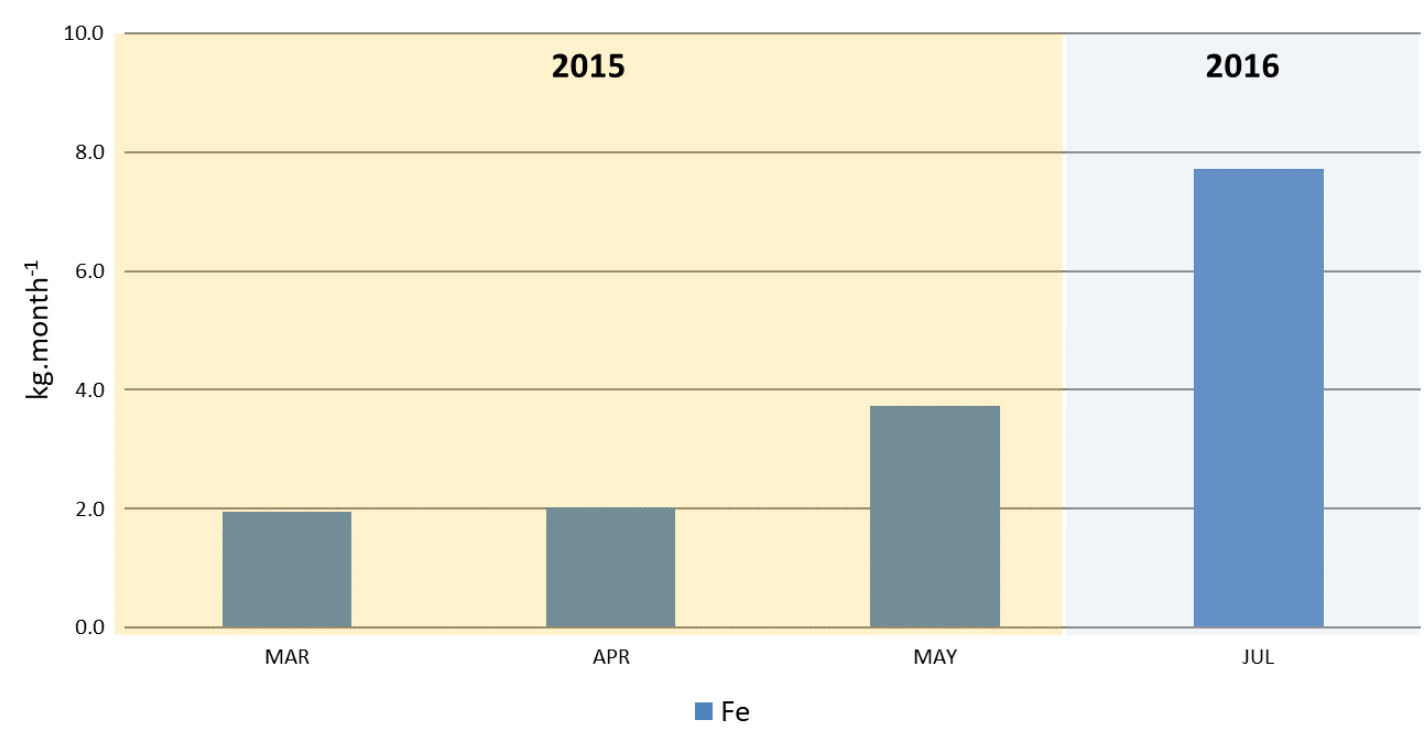

Figure 1: Iron Polluting Load considering operating regime 8h a day, 5 days a week 


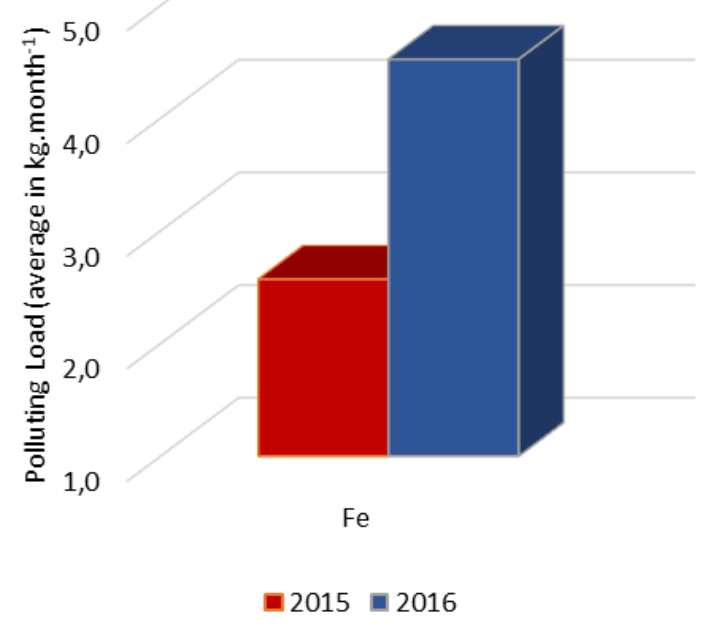

Figure 2: Monthly average of Iron polluting load in 2015 and 2016

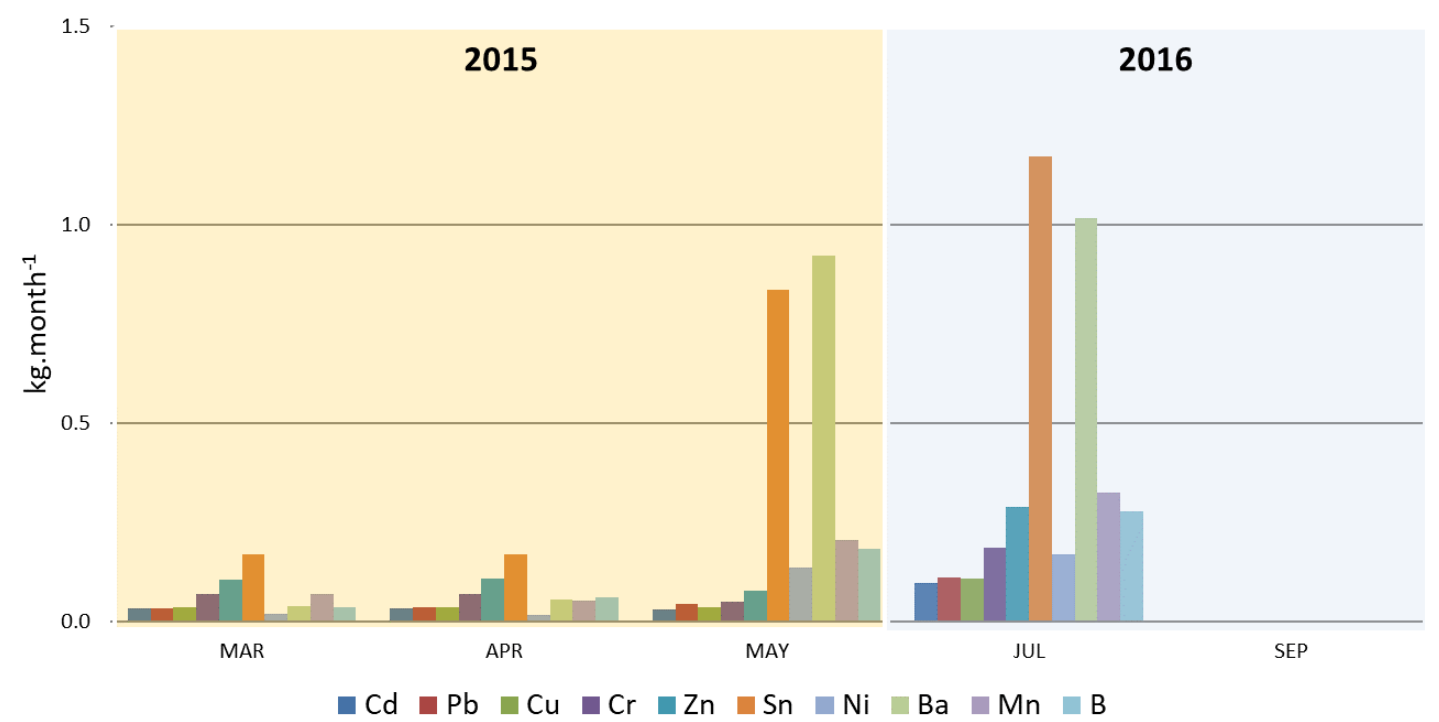

Figure 3: Metals and Semimetals Polluting Load (considering 8h a day/ 5 days a week as the operating regime) 


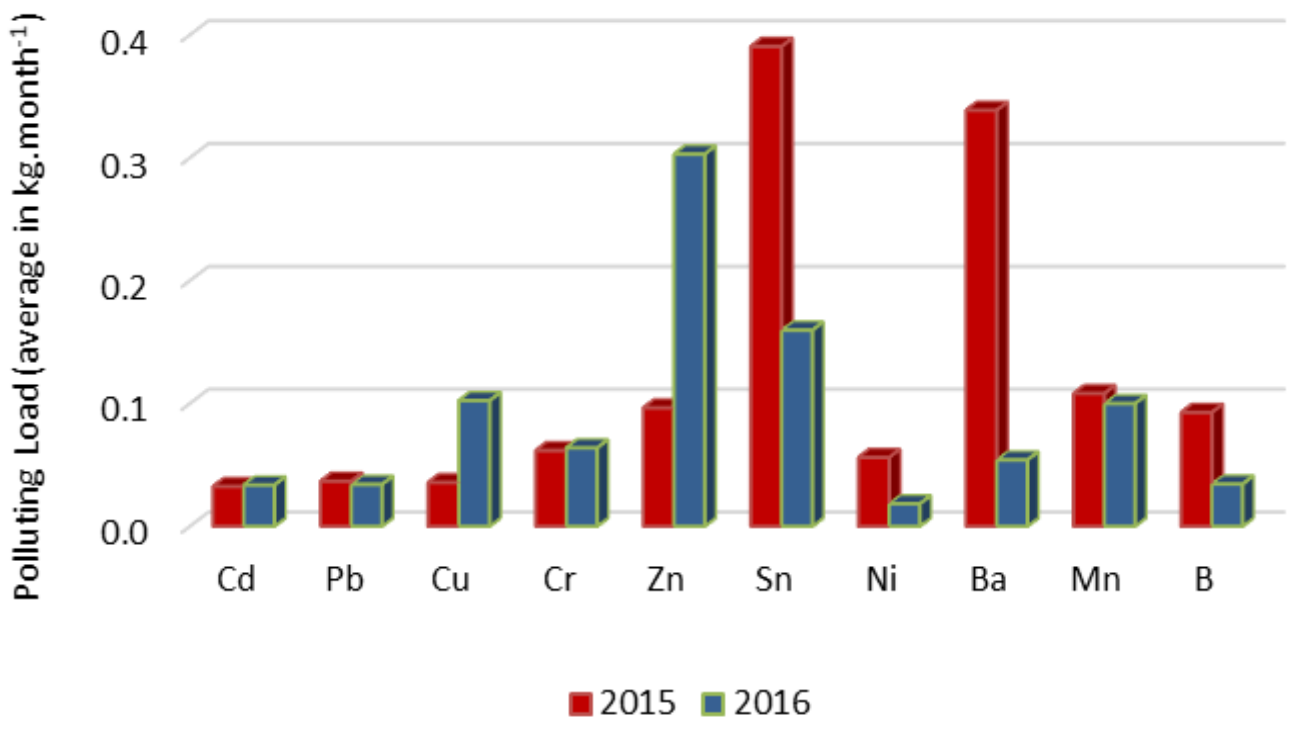

Figure 4: Average monthly polluting load for metals in 2015 and 2016

\subsection{Total Solids and its Fractions}

By the series of solids evaluation, it was observed that in 2015 and 2016, IPEN`s wastewater was composed mostly of VTS, associated with organic matter. While the FTS that groups inorganic salts, as sulfated and chlorides was reduced. The VTS corresponded to $54 \%$ and $51 \%$ of the Total Solids, in 2015 and 2016, respectively (see Figure 5)

Considering that the FTS corresponds to metals oxides, as non-volatile substances, by the elemental analysis, the oxides were a small fraction of FTSor approximately $1.4 \%$ to $4.4 \%$ in 2015 and 1.7 to $3.1 \%$ in 2016 . Therefore, the FTS polluting loads were expressively higher than the metals oxides polluting loads assessed. The low percentage of metal oxides in the FTS was attributed to the fact that the oxides of $\mathrm{Na}, \mathrm{K}, \mathrm{Ca}, \mathrm{Mg}, \mathrm{Al}$, etc, were not accounted for. We also notice that the IPEN`s water consumption was reduced around $30 \%$ between 2015 and 2016, the total solids polluting load increased by $60 \%$ in the same period. 


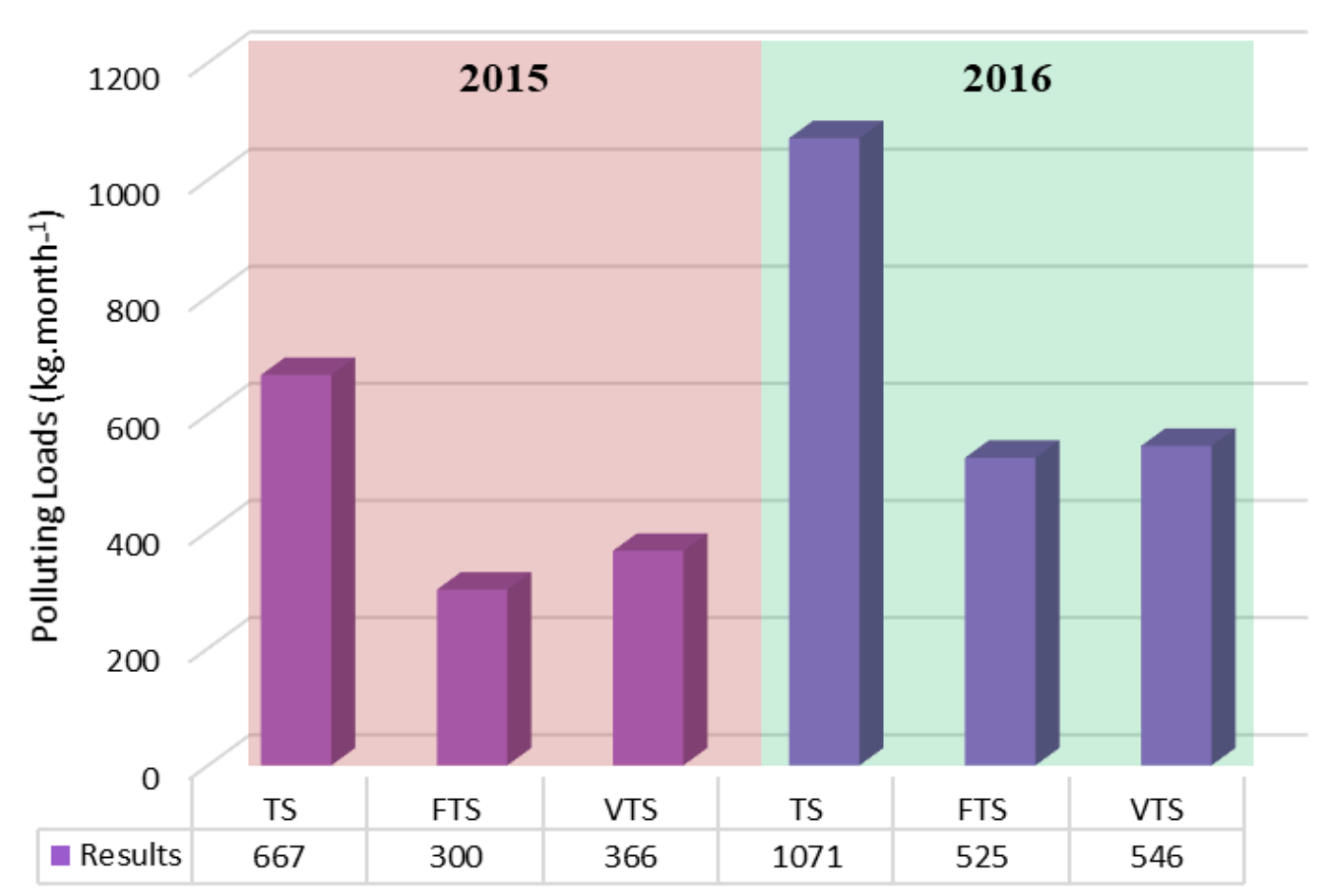

Figure 5: Monthly TS, FTS, and VTS polluting loads in 2015 and 2016

\section{CONCLUSION}

Using the information published by Silva et al. [6] and Marques et al. [7], the metal and solid polluting load released by IPEN in 2015 and 2016 were estimated. These results were compared with the polluting load released in 2013 and 2014. Using the IPEN`s water consumption, the overestimation of the wastewater flow rate was identified, based on the operating regime of the institute.

From 2012 to 2016, water consumption in IPEN decreased by $50 \%$. That probably leads to an increase in the average of metal and total solid polluting load released by the institute, when compared with values from 2013 and 2014. In this paper, a more appropriate operating regime was considered. The increase of Fe and FTS polluting load, observed in 2015 and 2016, was not linked to any specific activity at IPEN, but to eventual soil leakages into the wastewater pipe systems. Moreover, the release pattern of the institute was considered to present isolated events, concentrated in a specific period, possibly affecting the average monthly of Total Solids and Metals polluting 
load. The continuous reduction in the collection frequency observed, from the early monitoring years up to 2016, could be a source of larger uncertainty for the presented values. The lack of information during these months can be considered as a non-compliance to Brazilian regulations. The reduction in wastewater monitoring activities increases the uncertainties and opens blind spots, once there is no other way to prove Ipen's wastewater offer no harm to the general population.

More than to keep the assessment of the polluting load released, this paper contributes to the improvement of the estimation method and was possible to identify the main pollutants in the area. Then, a metals polluting load reduction goal can be proposed, as required by the agreement firmed between IPEN and IBAMA, to meet the environmental legislations. 


\section{ACKNOWLEDGMENT}

The authors thank IPEN-CNEN/SP, especially to CEQMA group, and to CNPq for financial support (Process nº 444323/2018-0).

\section{REFERENCES}

[1] MARQUES J. R., Otimização e validação de metodologia analítica para determinação de metais e semimetais em efluentes líquidos por espectrometria de emissão óptica com plasma de argônio (ICP-OES). Dissertação (Mestrado em Tecnologia Nuclear - Materiais) - Instituto de Pesquisas Energéticas e Nucleares, Universidade de São Paulo, São Paulo, 2015. Available at: <https://teses.usp.br/teses/disponiveis/85/85134/tde-11022016-132739/pt-br.php>. Last accessed: 10 Mai 2020.

[2] BRASIL, Resolução CONAMA 430, de 13 de maio de 2011, Brasília: Ministério do Meio Ambiente, 2011. Available at: <http://www2.mma.gov.br/port/conama/legiabre.cfm?codlegi=646>. Last accessed: 12 Mai 2020.

[3] BRASIL, Resolução CONAMA 357, de 17 de março de 2015, Brasília: Ministério do Meio Ambiente, 2015. Available at: <http://www2.mma.gov.br/port/conama/legiabre.cfm?codlegi=459>. Last accessed: 12 Mai 2020.

[4] PINTO C. C., "Importância da Avaliação de Dados de Concentração e de Carga de Poluentes em Bacias Hidrográficas: Exemplo da Bacia do Rio Verde”, Belo Horizonte, 2016, pp.1-9.

[5] SÃO PAULO, Decreto Estadual 8.468, de 8 de setembro de 1976, São Paulo: Assembleia Legislativa do Estado de São Paulo, 1976. Available at: < https://www.al.sp.gov.br/norma/62153>. Last accessed: 12 Mai 2020.

[6] SILVA D. B., FAUSTINO M. G., MONTEIRO L. R., COTRIM M. E. B., and PIRES M. A. F., "Bromide as chemical tracer to measure the liquid effluent flow at IPEN-CNEN/SP," in INTERNATIONAL NUCLEAR ATLANTIC CONFERENCE, Recife, PE, 2013.

[7] MARQUES J. R., MONTEIRO L. R., SOARES S. M. V., STELlATO T. B., SILVA T. B. S. C., SILVA D. B., FAUSTINO M. G., PIRES M. A. F., and COTRIM M. E. B., "Estimation of 
Metal Pollutant Loads from Nuclear and Energy Research Institute (Brazil)", in INTERNATIONAL NUCLEAR ATLANTIC CONFERENCE, São Paulo, BR, 2015

[8] PIRES M. A. F., SOUZA W. H., "Relatório Anual da Gestão Ambiental do IPEN”, São Paulo, BR, 2016. Available at: <https://www.ipen.br/portal_por/conteudo/documentos/REL_GES_AMB_IPEN_2016\%20ciclo\%2 02017.pdf>. Last accessed: 15 Mar 2020.

[9] CETESB - Companhia Ambiental do Estado de São Paulo, "Guia Nacional de Coleta e Preservação de Amostras: água, sedimento, comunidades aquáticas e efluentes líquidos”. 2011. Available at: <https://arquivos.ana.gov.br/institucional/sge/CEDOC/Catalogo/2012/GuiaNacionalDeColeta.pdf>. Last accesse: 25 Fez 2020.

[10] APHA AWWA WPCF, Standard Methods for the Examination of Water and Wastewater, 22nd Revised Edition, USA: American Public Health Association. 2005.

[11] U.S.EPA - United States Environmental Protective Agency. Method 3015A (SW-846): Microwave-Assisted Acid Digestion of Aqueous Samples and Extracts. Revision 1. Washington DC. 2007.

[12] CETESB - Companhia Ambiental do Estado de São Paulo, "Significado Ambiental e Sanitário das Variáveis de Qualidade das Águas e dos Sedimentos e Metodologias Analíticas e de Amostragem", São Paulo, BR, 2009. Available at: https://cetesb.sp.gov.br/aguasinteriores/publicacoes-e-relatorios/. Last accessed: 18 May 2020.

[13] ABNT - Associação Brasileira de Normas Técnicas. NBR 10.664: Waters - Determination of Residues (Solids) - Gravimetric Method - Method of Test. 1989.

[14] ISACKSON B., IRIZARRY L. "Rodenticide Toxicity" in: StatPearls [Internet]. Available from: https://www.ncbi.nlm.nih.gov/books/NBK554428/. Last accessed: 10 Dez 2020 